DOI https://doi.org/10.36059/978-966-397-108-7/2-20

\title{
LAND POLICY OF THE SOVIET GOVERNMENT IN CRIMEA IN 1920'S
}

\section{Horiunova Y.}

\section{INTRODUCTION}

The periods of reforms are always painful for the population, because they are accompanied by radical changes in the socio-economic and political structure of the state. While the greatest problems arise in postrevolutionary periods, where the destruction of the old system and the creation of new political and economic grounds are taking place.

Crimea population have faced with these problems in 1920s when they found themselves in a new reality created by Soviet power authorities. The main factors of Bolsheviks policy in this period in Crimea, as well as throughout the country, are the fulfillment of their main promises - the liquidation of land tenure of the landlords and the redistribution of these lands among peasants, taking into account the regional features of Crimea - the presence of landless areas and the multinational composition of the peninsula population.

The redistribution of land among the peasants required new economic rules which were implemented within the framework of the new economic policy with its multi-layered nature of the economy, lease, use of hired labor and market relations in the countryside. But, as time shows, all these outgoings were temporary and aimed at solving the food problems.

The land policy of the Bolsheviks was based on a class approach, which determined the priority of collective farms before individual ones, which had to disappear gradually on the path of further socialist transformations. Therefore, the Soviet authorities in every way supports not the land owners, but the poor- farmhand elements of the village, which should have become the basis for future collectivization.

Because of the class logic new economic policy in the Crimean countryside was crushed and the peasants was forced to join collective farms as they were threatened by dispossession, which was accompanied by deprivation of not only political, but civil rights. 


\section{The features of the Bolsheviks agrarian policy in Crimea under the power of Soviet Union}

The first document, which outlined the basic principles of socialist transformation in the Crimean countryside was adopted in January 1918 by the decree on the socialization of land. According to the document, the private ownership for land was permanently canceled, the land was transferred without any redemption to "labor peasants". That is, the land could only be used by those who really process it by their own work.

The decree also listed natural and legal persons who were entitled to have land. Among them, above all, there were listed the state through the organs of Soviet power; public organizations controlled by the power authorities; the agricultural communes and associations, as well as rural land associations; commercial, industrial, and transport enterprises; individual families and individuals who do not use land for income generation. The land was handed over to use, first of all, to those who wished to work for it not for their own benefit, but for the sake of the public good ${ }^{1}$.

On February 19, 1919, the All-Russian Central Executive Committee (ACEK) and the Council of People's Commissars (CPC) of the Russian Soviet Socialist Republic (RSFSR) adopted the Law "On the Land of the Crimean Soviet Socialist Republic (CSSR)". This law was needed in order to embody the general principles of Soviet Russia land tenure taking into account the regional features of the Crimea.

For the purpose of socialist justice in the division of land all Crimean land was divided into the main and secondary land funds. The main fund consisted of so-called "former non-labor households" lands. It was intended to provide the land for poor and landless peasants, as well as for Soviet farms (state farms). The reserve fund was formed from the remaining lands, and was intended to satisfy the land needs of the Crimean Tatars who returned to the Crimea from emigration.

First of all, the land should have been provided for poor and landless peasants who were engaged in agricultural labor in the Crimea before February,19 1918. In the second place, land plots were intended for agricultural purposes of population, which appeared in Crimea after February 19, 1918 Another part of population of the peninsula had the opportunity to get land in the last turn.

\footnotetext{
${ }^{1}$ Третий Всероссийский съезд Советов. Госиздат, М., 1918. С. 33-47.
} 
The law sets the terms of land use for cultivation -9 years, and for the cultivation of perennial crops -15 years.

The land plots were given to peasants for use from main funds in accordance with the Crimean commissariat of land relations (narcomzem) standards. In each of the 30 climatic-ground regions of the peninsula the special land standard was established ${ }^{2}$.

In total, three main agricultural zones of Crimea were created, depending on the climatic conditions and features of the soil. In accordance with these features a certain specialization zones were defined: animal husbandry and field farming for the steppe zone; gardening, viticulture, tobacco - for the mountain zone; and the mixed type of farms for the foothills zone.

However, due to the continuation of the Civil War, this law was never implemented on the peninsula. But after the final victory of the Soviet power in the Crimea this document was taken as the basis for conducting land policy in the Crimea.

The first step of the Bolsheviks in the land - nationalization of land on the southern coast of Crimea - from Sudak to Sevastopol. Not only the land of private individuals, but also the possession of various institutions and organizations were nationalized. A few months later, nationalization cover the entire peninsula. However, Bolsheviks did not hurry to transfer the nationalized lands to the peasants, planning to place on them more than 1,000 Soviet collective farms - state farms.

The regional conference of the Russian Communist Party of the Bolsheviks (RCP (b)) held in May 1921 defined the basic principles of land policy in the Crimea for the coming years. The main task of the communists in the countryside was to implement a policy of social differentiation of the population, which will allow the poorer and middle classes of the countryside to be attracted to the side of the Soviet power, without support of these parts of population it was difficult to count on Proletarian revolution success in the agrarian country. In addition, the agricultural sector of the Crimea should have become an example for other peoples (especially the Muslim East), so the Bolsheviks hoped to raise the agriculture of the peninsula to "such a height that it did not achieve under capitalism." But for it was necessary to conduct a powerful

\footnotetext{
${ }^{2}$ ДААРК (Державний архів Автономної Республіки Крим). Ф. 1. Оп. 1. Спр. 53. Арк. 80.
} 
struggle against all manifestations of capitalist relations in the countryside ${ }^{3}$.

There were proclaimed specific ways of solving these problems: 1) full expropriation of non-labor lands and their socialization; 2) extermination of capitalist relations in the countryside through undermining economic positions of the most powerful layer of the peasantry; 3) satisfaction of the poor peasant's land hunger at the expense of the kulaks ${ }^{4}$.

The Crimean Bolsheviks tried to justify such a policy with the help of Marxism, which, in their opinion, insisted on "the inevitable death of agriculture in the process of economic development". Accordingly, the individual peasant economy is doomed, and the collective forms should be the main alternatives: 1) state farms as indicative examples of a new culture of production in the village - "farm as a grain mill"; 2) the agricultural labor communes as a product of rural proletariat independence and 3) agricultural artels and societies as a transitional form on the way to socialization of agriculture ${ }^{5}$.

But such a land policy of the Bolsheviks was not understood by the majority of the Crimean peasants, who were expecting from the Soviet power a fair distribution of land, but received the requisitioning with the withdrawal of almost all food.

Against the background of the socio-economic situation deteriorating in Crimea the "white-green movement", consisting of the remnants of White Guard movements supporters who could not be evacuated from the peninsula together with the army of Wrangel, and the Crimean Tatars, who were most not satisfied with the land policy of the Bolsheviks, was unfolding.

The Crimean authorities saw this movement as "political gangsterism" which they tried to destroy with the help of military units. In the spring of 1921 a number of punitive operations were carried out in a single block, but the number of "white-green" supporters was increasing, along with the area of its distribution through the Crimean territory ${ }^{6}$.

\footnotetext{
${ }^{3}$ РЦХИДНИ (Российский центр хранения и изучения документов новейшей истории). Ф. 17. Оп.16. Спр. 178. Арк. 16.

${ }^{4}$ Там само. Арк. 27.

${ }^{5}$ РЦХИДНИ. Ф. 17. Оп.16. Спр. 178. Арк. 27.

${ }^{6}$ Ішин А. В. Антибільшовицькі виступи у Криму і боротьба з ними (кінець 1920-1925рр.): автореф. дис... канд. іст. наук: спец. 07.00.01 Історія України. Дніпропетровськ, 2002. 12 с.
} 
The situation was so complicated that a special commission from the Central Executive Committee and the Council of People's Commissars of the RSFSR came to Crimea from Moscow, the goals of such visit were formulated in the "Addressing to the Labor Population of Crimea". The Soviet Communists stressed that their main mission was to eliminate misunderstandings and conflicts that arose due to the "inefficient, and sometimes criminal actions of individuals and institutions", having in mind the Crimean power authorities. Commission members promised to deal with the situation, to correct the mistakes and to punish the perpetrators. Crimeans also promised to reorganize local power authorities and provide real autonomy, "taking into account local characteristics"7.

The Moscow Commission begins to collect complaints about the actions of local authorities - in two weeks it was given 65 collective letters from the peasants. Considering the land policy aspects on the peninsula, the Commission has identified that the food campaign in the Crimea started in good conditions - after the evacuation of the White Guard troops from the peninsula a lot of food left. But the arrival of new parts of the Red Army on the peninsula required more products. Therefore, the Crimean authorities send out the Soviet troops to Crimean farmers in order to take food, they were operating in the countryside as "war communism" since the Civil War.

On the other hand, Moscow set unrealistic food requisitioning norms to Crimea, which did not take into account the real state of the Crimean agriculture. The consequence of such a policy is the rapid impoverishment of the Crimean population. "At the moment, the food situation in Crimea is catastrophic. We have 75,000 pounds of bread in the presence of 108,000 eaters from military institutions and 200,000 public institutions and enterprises," - the Commission has noted in the report ${ }^{8}$.

All this forces the Russian authorities to cancel the food requisitioning, although most of the food has already been expropriated. For example, of 2 million pounds of grain already harvested 1560646 pounds (i.e. 78\% of the plan). Of the planned $2,400,000$ pounds of fodder grain it was possible to raise more than half -1234121 pounds $^{9}$.

The members of the Moscow Commission realized that it was simply impossible to take more food in the Crimea, and further pressure on the

\footnotetext{
${ }^{7}$ РЦХИДНИ. Ф. 17. Оп.13. Спр. 508. Арк. 6.

${ }^{8}$ РЦХИДНИ. Ф. 17. Оп.13. Спр. 508. Арк. 48.

${ }^{9}$ Там само. Арк. 50.
} 
local population could lead to very serious consequences. Therefore, it was better to admit that "political gangsterism" in Crimea is a consequence of the unsuccessful land, food and national policy of the Crimean authorities.

This solution allowed to appoint in July 1921 near Alupka meeting between members of the Commission and local authorities on the one hand, and the commanders of "white-green" units on the other hand. During the meeting an agreement was reached on the handing over of weapons by "white-green" units for two weeks. In exchange for this they were guaranteed amnesty ${ }^{10}$.

In addition, during the talks, the Soviet authorities tried to attract the Crimean Tatars on their side promising them not only to resolve the land issue, but also the real autonomy of Crimea and places in state authorities.

In August 1921, the Crimean Land Department published an appeal to Crimean farmers, promising them to respect the peasants' right to use land "which they can process by their own families." Bolsheviks promised that in landless regions the peasants would be given the land of collective farms and state farms that are not of national importance ${ }^{11}$. However, these promises were not fulfilled: by the end of 1921, the needs of landless and poor land peasants were not satisfied, it caused a new wave of peasant dissatisfaction.

At the same time, the economic situation in the Crimea is significantly deteriorating. In the autumn of 1921, the Crimean authorities are turning to Moscow for food aid, but the power authorities of RSFSR refuse to recognize Crimea as a starving region until February 1922, when more than half a million people ( $60 \%$ of the population) are starving on the peninsula.

In December 1921, 2,000 persons have died of starvation on the peninsula, and in January 1922 this figure has reached almost 10,000. During the next time the number of deaths grew very fast: 14864 people in February, 19869 - in March, 23353 - in April, and 32053 - in May. In general, according to official figures, over half a year in the Crimea, more than 160 thousand persons have died from starvation. But these data are not final. "In the cities we registered only those corps that were buried by the utility services, while the religious communities burial - Jewish,

${ }^{10}$ Ішин А. В. Антибільшовицькі виступи у Криму і боротьба з ними (кінець 1920-1925 рр.): автореф. дис... канд. іст. наук: спец. 07.00.01 Історія України. Дніпропетровськ, 2002. 13 с.

${ }^{11}$ ДААРК. Ф. 1. Оп.1. Спр. 71. Арк. 7. 
Karaite, Armenian, Greek, and others, as well as private individuals are not included in these numbers" - said the head of the Crimean Central Executive Committee (Crimean CEC) Haven ${ }^{12}$.

The situation in cattle breeding was horrible: only $40 \%$ of sheep, $25 \%$ of cows, $21 \%$ of horses and $2 \%$ of pigs in Crimea remained in comparison with 1916. At the end of 1921, the Crimean peasants did not even have seed grain ${ }^{13}$. The area of sowing during the 1920-22 period was reduced by 2 times in the Crimea - from 491249 to 186505 acres.

This situation was due to objective reasons (dry summer of 1921), and this was also the result of the irresponsible policy of the Crimean authorities, which, through the use of class approaches in the countryside, focused on the collective farm building instead of providing the Crimean peasants with real land.

The socio-economic crisis was characteristic not only for the Crimea, but it also covered the whole Soviet Russia. Therefore, at the X AllRussian Congress of Soviets in December 1922, the resolution was adopted "On Approaching and on the strengthening and development of agriculture", which emphasizes the implementation new land policy principles that will be reflected in the Land Code.

It was adopted in December 1922 by the Land Code to organize measures on tax policy in the countryside in order to develop the most profitable from an economic point of view branches; it was declared a partial transition from natural taxes to money, the opportunities for peasants' cropping were extended, as well as the necessary measure for the development of agriculture is determined by the maximum increase in sown area ${ }^{14}$.

The Land Code establishes the right to endless use of land, but there was prohibition for its purchase and sale, will, gift, but it allows the labor lease of land - the processing of leased land by the forces of peasant own economy. Hired labor could only be used if all able-bodied household members were involved in the processing of land alongside with hired workers.

However, the most attention in the Code focuses on the collective forms of land use, that is, the processing of land by the communes, state

\footnotetext{
12 ДААРК. Ф. 1. Оп.1. Спр. 81. Арк. 3-4.

13 ДААРК. Ф. 1. Оп.1. Спр.314. Арк. 165

14 Хронологическое собрание законов, указов Президиума Верховного Совета и постановлений правительства РСФСР. Том. 1. М., 1949. С. 85-86.
} 
farms and collective farms, which for the Bolsheviks remain the main participants in land relations in the countryside ${ }^{15}$.

Thus, the first steps of Soviet power in the Crimean countryside were connected with the realization of the methods of "military communism" with its overproduction, which caused a strong resistance of the local population. To stop the struggle of the peasants, the Bolsheviks were forced to move to other forms and methods of land policy on the peninsula.

\section{Agrarian policy of Soviet authorities in the Crimea in 1924-29 years}

In the 1921-1925 years the main problem in the land policy in Crimea was division of land between the cities, countryside, towns, collective and state farms and various institutions.

Since 1925, power Crimea begins to distribute land in the countryside, which was aimed at determining the boundaries of each peasant household separately. This task was fulfilled by the Bolsheviks from class positions. First and foremost, land was used for poor households, which was given the best land at the state expense. Land management of other farms was carried out in the second turn and at the expense of the peasants themselves.

The launch of the Land Code in 1923 revives the situation in agriculture - the recognition of restrictions on the lease of land and the use of hired labor expands the capabilities of the Crimean peasants. But these limited measures did not allow to exceed the level of pre-war and revolutionary years. So, if in 1917 the size of the sown area is 697095 acres, then in 1923 in other though grows in comparison with the previous years, but it reaches only 265358 acres (2 times less than in 1917). In 1924, the Crimean crop area has increased by another 39749 acres, but to a large extent it inferior to the pre-Soviet level ${ }^{16}$.

The Bolsheviks did not succeed in reaching pre-revolutionary harvesting rates. If in 1916 in the Crimea collected 12.5 million pounds of wheat, then in 1924 - only 5.2 million. Accordingly, the harvest of barley has decreased from 6.7 to 2 million pounds, oats - from 3 to 0.6 million.

\footnotetext{
15 Земельный Кодекс РСФСР. М., 1923.

${ }^{16}$ РЦХИДНИ. Ф. 23. Оп. 14. Спр. 185. Арк. 14-15.
} 
If in the years 1916-17, it was 57-60 pounds of grain per one peasant, then in 1924 - only 27.6 pounds ${ }^{17}$.

1925 year was exceptional as the most productive one. That year it was possible to exceed the harvest of pre-revolutionary times. In the same year, the number of sown area in the Crimea is increasing to 450 thousand acres of land. This growth continues further, almost reaching in the 1926-27 pre-war levels of 650 thousand acres of land ${ }^{18}$. The increase in agriculture in 1925 was due to the removal of restrictions on land lease and the use of hired labor force.

However, these actions to the peasants were only a temporary and compulsory measure aimed at both increasing production in the agricultural sector and strengthening ties with the peasants who, according to Lenin, cited by Stalin in 1925, "cannot live in these conditions without commodity turnover, without the admission of a certain revival of capitalism" $" 19$.

The new economic policy in the countryside had several important results. Firstly, due to the partial representation of market relations, the economic situation in the agrarian sector improves - crop areas and yields increase. On the other hand, the process of rapid social differentiation takes place, when on one pole we have broad stratum of the rural proletariat, and on the other - a layer of wealthy households, the so-called "soviet kurkul" on which Bolshevik power, guided by the class ideas of Marx and Lenin, exerts economic and political pressure. Such a policy did not contribute to increasing the profitability of rural masters, because they could quickly be classified as "kulaks" with all the consequences of such a process - future dispossession, deprivation of political rights and exile.

Because of such an agrarian policy during the 1920s the value of gross agricultural products in the Crimea declined from 87 rubles 90 cents in 1923 to 58 rubles 63 cents in $1928-29^{20}$.

The problematic situation also arises with the special culture raised in the Crimea. The area of the gardens in 1916 was equal to 13857 acres and yield up to 3.855 million tons per year, then the on maximum area of 9600 acres in 1928 the harvest does not exceed 980,370 pounds (4 times

\footnotetext{
${ }^{17}$ РЦХИДНИ.Ф. 17. Оп. 14. Спр. 13. Арк. 2.

18 ЦГА РФ (Центральный государственный архив Российской Федерации). Ф. 2313. Оп. 13. Спр. 148. Арк. 9.

${ }^{19}$ Сталин И. Сочинения. Госполитиздат. М., 1947. Т. 7. С. 357.

${ }^{20}$ РЦХИДНИ. Ф. 17. Оп. 16. Спр. 118. Арк. 15.
} 
less). The largest crops were harvested in 1925 and 1926, when the Soviet government was forced to make concessions and expand the conditions for renting land and using hired labor. That is why in 1925 in the Crimean gardens 1566000 pounds of fruit were harvested, and in 1926 1980000 pounds. But already in 1929 the harvest decreased to 767000 pounds, which is 2.5 times less than in 1926, and 5 times less than in the pre-Soviet period ${ }^{21}$.

In 1916, the Crimean vineyards occupied the area of 7469 acres, on which one million pounds of grape was harvested. In 1926 there were already 8649 acres under vineyards, but the harvest is only 960 thousand pounds. This was the maximum figure for the twenties. The next year the area of vineyard is much smaller (the area has decreased for $35 \%$ - up to 5600 acres) and the yields has reduced almost 2 times - up to 505 thousand tons ${ }^{22}$.

The tobacco plantations in Crimea occupied an area of 4,145 acres of land in 1916, from which it was harvested more than 207 thousand products. Only in 1925 and 1926 the Crimean peasants managed to collect more tobacco than in the pre-Soviet period - 275 and 295 thousand pounds respectively. However, since 1927, tobacco plantations have been significantly reduced (up to 3,000 acres), and the yields has been reduced twice - to 147,000 pounds in $1929^{23}$.

So in the late twenties Crimean gardens gross output decreased by 5 times, vineyards -2 times, tobacco - by 1.5 times.

Crimean animal husbandry suffered a powerful blow from Soviet times. In ten years (1916-1926), the number of horses decreased from 166564 to 75697 (that is, 2.2 times), cattle - from 163645 to 94179 (1.7 times), sheep from 462021 to 288,680 (1,6 times), pigs - from 70,847 to 42,820 (1,7 times). It's only the number of goats has been increased - 2.1 times - from 16337 to $35117^{24}$.

After removing some restrictions 1927-28 it was managed to increase the number of horses to 114 thousand heads, and the number of cattle increased to 156 thousand (almost to the level of 1916). However, the

\footnotetext{
${ }^{21}$ ЦГА РФ. Ф. 2313. Оп. 14. Спр. 117. Арк. 28-30; ДААРК,. Ф. Р-30. Оп. 2. Спр. 7. Арк. 84.

${ }^{22}$ Народное хозяйство Крыма за 1927/1928 год. Симферополь, 1929. С. 11-12.

${ }^{23}$ Народное хозяйство Крыма за 1927/1928 год. Симферополь., 1929. С. 11-12.

${ }^{24}$ Народное хозяйство Крыма за 1927/1928 год. Симферополь., 1929. С. 14.
} 
livestock of the sheep decreased to 200 thousand heads (compared with 1926), the number of pigs and goats almost did not change ${ }^{25}$.

Since the Bolsheviks in ten years after the "October victory" failed to exceed the level of Tsarist Russia in the agricultural sector of the Crimea, Soviet officials tried to manipulate figures actively and create fake statistics in order to demonstrate growth which does not correspond to reality. As a result, in the reports of the Party and Soviet bodies of the Crimea there were fictitious indicators ("hollow numbers") that demonstrate to Moscow the seemingly positive development of agriculture on the peninsula.

Such false statistics were reported to the Fourth Plenary Meeting of the Crimean Regional Committee. In the session of the All-Union Communist Party of the Bolsheviks (the Communist Party (b)) at the end of 1929. "All the time, they are talking about an increase in sown areas. We must say that there are exaggerating in a number of sown areas by People's Commissariat of Land Relations - the hollow figures. The reality of these figures is not taken into account at all, they do not have any economic justification. And when we raised the issue of the reality of these figures, they were given the answer: "You have given control figures and no changes will be made. The fact that you are not able to reach it, we know ourselves because they are not feasible," said the secretary of the Kerch Regional Committee of the CPSU (b) ${ }^{26}$.

Thus, agriculture of Crimea in 1920 did not reach the level of prerevolutionary not by sown area, nor by the gross yield of both cereals and special crops, or by livestock.

Such a development was due to a number of factors. First, in 1919, emphasizing the alliance of the working class with the middle peasantry, the Soviet government continued to rely on the poor man and farmhand who almost did not produce anything.

According to the sample surveys of farms of the Crimean poor man, most of them did not have their own crops. For example, in 1924 there were 24 thousand unscrupulous farms in the Crimea. As a result, instead of sowing 250,000 acres (as it was planned by the Crimean authorities), only 181,000 acres were sown (by one third less) ${ }^{27}$.

\footnotetext{
${ }^{25}$ Народное хозяйство Крыма за 1927/1928 год. Симферополь., 1929. С. 15.

26 ДААРК. Ф. 1. Оп. 1. Спр. 854-а. Арк. 26-27.

${ }^{27}$ Красный Крым, 1924, 1 марта.
} 
In autumn, during the sowing campaign of 1929, the Crimean authorities planned to increase the sown area by $36.8 \%$, but managed to fulfill the plan only for $69 \%$. This indicated that some peasants were not interested in expanding crops and raising yields. These were the very poor strata, who had many privileges from the state - for example, they were exempted from paying taxes.

"If we look for figures of the People 's Commissariat of Finance of the Crimea, then you can see the following: $24 \%$ of households, that is, the poor peasants exempted from tax. There were 19335 farms. In some regions, the number of farms exempted from agricultural tax reaches 60-65\%. In some regions of countryside the tax is not paid at all," reported in 1927 the People's Commissar for Land Relations Memetov ${ }^{28}$.

In the late 1920s, all the poor peasants and farmhand were exempted from paying agricultural tax. However, according to data from the sample surveys of the budgets of the Crimean peasant farms, it did not affect the level of their lives - they were fed no worse than the middle classes who worked actively on land and pay taxes. Comprehensive support of the poor peasants in the context of the Bolsheviks' use of the class approach in the Crimean countryside killed the desire of peasants to expand farms and increase yields.

Thus, the Soviet authorities actually cultivate poverty among the Crimean peasants, because only in the rural proletariat they see a real support to the regime. It was the poor man who wanted to become a bulwark of mass collectivization in the countryside, to which Moscow was actively preparing.

For the wealthy peasants the situation was even worse, since from the second half of the 1920s they bear the main burden of agricultural tax. In 1928-1929, the full amount of the tax was completely transferred to the "kulak" economy. Interestingly, during the 1924-27 years in the reports of the Crimean authorities "wealthy peasants and kulaks" were identified. But in 1928-1929 years all more or less prosperous household were identified as "kulak" which must be dispossessed.

In February 1929, the CEC and the SNK of the USSR adopted a new law on agricultural tax, which completely exempts poor households from taxation and introduces individual taxation for kulak farms.

\footnotetext{
${ }^{28}$ ЦГА РФ. Ф. 2313. Оп. 16. Спр. 18. Арк. 123.
} 
In complying with this law, the Crimean Regional Committee of the CPSU (b) requires local Soviet authorities to adhere strictly to the class approach when taxing peasants in the peninsula. At the end of 1929 secretary of the Crimean Regional Committee of the CPSU (b) Zhivov reported to Moscow about the plan of grain deliveries. "We take all measures to implement as quickly as possible the plan for all hundred percent. From this point we strengthen the pressure on kulaks" - he wrote $^{29}$.

Moscow responded to the Crimean Communists by telegram signed by the candidate for the Central Committee of the CPSU (b), Lazar Kaganovich, who clarified the main principles of work in the countryside to the Crimean authorities from the Central Committee of the Communist Party by November 3, 1929. Firstly, the Party and Soviet local authorities needed to focus their attention on grain supplies. Non-fulfillment of the plan in Moscow was seen as a lack of pressure on the kulaks, "which is a reflection of the rigid implementation of the party line." The central government offered to accelerate grain procurement by means of punitive measures involving the United State Political Department (USPD) - a special body of state security of the USSR ${ }^{30}$.

Political struggle in the countryside led to the fact that economic problems fell into the background. The Bolsheviks constantly emphasized that an individual peasant economy is an anachronism and does not correspond to the tasks of the socialist construction. Therefore, the policy documents of the Central Committee are increasingly requiring more rigorous measures against the kulaks. One of the directives of the Central Committee for the Crimean Regional Committee of the CPSU (b) in 1928 demanded "to carry out an immediate removal of all the kulak land without any compensation for the embedded work, or for additional plantings, and to give it to the poor peasant, which are organized in the collective farms."

In such conditions, many wealthy peasant farms, which became such after 1925, have not seen an incentive to expand crop yields and increase crop yields. Therefore, they either completely stopped working on their own farm, or they were engaged in the work without any interest in further development.

\footnotetext{
${ }^{29}$ ДААРК. Ф. 1. Оп. 1. Спр. 920. Арк. 58.

30 ДААРК. Ф. 1. Оп. 1. Спр. 920. Арк. 69.

31 ДААРК. Ф.1. Оп. 1. Спр. 837. Арк. 220.
} 
The Crimean peasants understood very well that the class struggle that was used in the countryside through tax policy did not create the conditions for the development of their farms and negatively affected the state of the agricultural sector of the peninsula. They were talking about it during the meeting were of the party leadership of Crimea. But these thoughts of the peasants were not taken into account, because they contradicted the Bolshevik`s ideology.

The policy of the Bolsheviks in the area of land use was uncertain: during the 1920s various directives concerning labor norms of land use were sent from Moscow. Thus, in 1921-23, land management was delayed under the pretext of seeking a compromise variant of the norm, which would have satisfied both the state and the peasants. Such a norm was determined only in 1924, when it was defined a special unit of land allocation. It was determined by three main indicators: 1) the peasant yard as a whole; 2) the number of able-bodied workers in it ; 3) the number of eaters in $\mathrm{it}^{32}$.

However, such an approach to the distribution of land caused criticism of those who had more workers and less eaters at the farm. Such peasant households had more opportunities to expand their farms than those where there was one or two able-bodied people.

As a result of the corresponding policy of Soviet power, land tenure standards in the Crimean countryside were constantly revised, which led to new redistribution of land.

On the other hand, during the 1920s, the Soviet authorities of Crimea carried out a number of relocations. Firstly, the peasants from the mountainous and foothill areas are relocated to the steppes (first of all, it concerns the Crimean Tatars). Secondly, peasants from other regions of the country are also relocated to the Crimea - first of all, this concerns the massive migration of the Jewish population to the peninsula.

For example, as of October 1, 1927, 2,408 families (10,714 eaters) were resettled in the borders of Crimea. Another 1,617 families came to the peninsula from outside, with an absolute majority of them - Jewish families $(96 \%)^{33}$.

The total area occupied by the settlers is 311793 hectares, of which more than 100 thousand hectares of land belong to the Jewish families ${ }^{34}$.

\footnotetext{
${ }^{32}$ РЦХИДНИ. Ф. 17. Оп. 13. Спр. 756. Арк. 13.

33 ДААРК. Ф. 1. Оп. 1. Спр. 644. Арк. 153.

34 ДААРК. Ф. 1. Оп. 1. Спр. 644. Арк. 5.
} 
The policy of the Jewish population resettlement in the context of unresolved issues of land management for the Crimean Tatars caused a negative reaction from the latter.

In addition, the provision of land to peasants was very slow, although local authorities had all the necessary legislative acts and land fund. The best land from among the former landlords' farms was not given to the peasants - it was provided for the creation of Soviet farms (state farms). Therefore, some peasants did not receive land for years and complained about it to the Party and Soviet bodies.

"At the beginning of 1921, we were announced about future work on land management, - the peasants of the Syuyurtash Land Association wrote to the Crimean Regional Committee of the CPSU (b). - Then we paid for the cost of land assignment. Despite this, the borders of the Syuyurtashs Land Association were not identified until February 1925, the issue of spare public land remains open"35.

During the 1920s, the norms of peasant land use changed often. Only on September 7, 1925, the Crimea Central Committee approved the "Regulations on the Procedure of Labor Land Use", which established the norms of land allocation. In the field of farming, they ranged from 13 to 40 acres of land to an average family of 6 people with 3 workers. The size of the rules depended on the conditions of the soil and the distance to the markets ${ }^{36}$.

Thus, to 1927 the average norms of land plots for peasants of Tatar nationality were increased from 11 to 21 acres of land, Bulgarians - from 15 to 23.2 acres of land, and other nationalities - from 20 to 24 acres of land. On the other hand, the amount of land for German peasants was reduced: if before the revolution they had 389,520 acres of land, then, after the Soviet land administration, only 221,063 acres remained in their use ( $44 \%$ decrease). This was due to the fact that half of the German peasants were large landowners. In Soviet times they left only 25 acres per household ${ }^{37}$.

As a result of land management work the number of lands cultivated by national minorities increased considerably: if, before the revolution, they had only 775,295 acres (half of it belonged to the Germans), then after the Soviet land tenure, they have 1,767,486 acres of land. For

\footnotetext{
${ }^{35}$ ДААРК. Ф. 1. Оп. 1. Спр. 382. Арк. 56-58.

${ }^{36}$ ДААРК. Ф. 1. Оп. 1. Спр. 457. Арк. 242.

${ }^{37}$ ДААРК. Ф. 1. Оп. 1. Спр. 457. Арк. 243.
} 
example, the land plots of Bulgarians increased by 34\% - from 39444 to 59580 acres, Greeks - 6 times (from 7436 to 44977 acres), Armenians 6.5 times (from 558 to 3594 acres). The Jews first received land plots with a total area of 120114 acres $^{38}$.

However, conducting land management work, the authorities of the Crimea were engaged primarily in creating conditions for the collectivization of peasant farms. As of May 1, 1927 , there were 423 collective farms in the Crimea, including 19 communes, 360 artilleries, 44 CPL (the company for the processing of land) ${ }^{39}$.

Crimean Tatars and Russians were most actively involved in collective farms - their share in various forms of collective land use was equal to $54.96 \%$ and $30.02 \%$ respectively.

Permanent fluctuations of the Soviet government in relation to land policy, delaying land management processes along with the application of class approaches to supporting the poor elements of the countryside and the oppression of wealthy groups negatively affected the economic potential of the agricultural sector of the peninsula. As a result, food prices have been rising steadily.

For example, for only one month in 1924 flour prices for rye increased by $309 \%$, for wheat - by $330 \%$. Potatoes went up by $412 \%$, beets - by $300 \%$, meat - by $274 \%$, milk - by $287 \%$, oil - by $275 \%$, and eggs - by $189 \%^{40}$. The similar situation was in the Crimea and later especially in 1928-29, when the state began an open class struggle against wealthy peasants who cut their own farms.

Such a policy leads to the fact that the bread for the urban population of Crimea in the late 1920's was already procured in the Ukrainian Soviet Socialist Republic (USSR). But, since the Soviet policy of curtailing individual farms was characteristic for the whole territory of the Soviet Union, there were also crisis symptoms in the Ukrainian food market, which leads to a reduction in the supply of bread and cereals for the peninsula.

Because of the shortage of food, the Crimean leadership was forced to appeal to Moscow to include the peninsula in the Ukrainian harvesting plan along with the Ukrainian regions. The government of the USSR

\footnotetext{
${ }^{38}$ ДААРК. Ф. 1. ОП. 1. Спр. 837. Арк. 83.

39 ДААРК. Ф. 1. Оп. 1. Спр. 924. Арк. 8.

${ }^{40}$ Красный Крым, 1924, 20 февраля.
} 
supported the Crimean authorities, obliging Ukrainian suppliers to send 100 food wagons to the Crimea ${ }^{41}$.

Thus, the problem of full recovery of the productive forces of the Crimean countryside during the 1920s. was not resolved. Crimean agriculture has not only become an exponential model, as planned by the Bolsheviks, but, on the contrary, it was in a state of deep crisis.

\section{CONCLUSIONS}

The policy of Soviet power in the Crimean countryside did not meet the interests of the most economically and hard-working part of the Crimean peasantry, but it was frankly the opposite. This led to the negative attitude of the majority of Crimean peasants to measures of Soviet power in the land, food and tax sectors.

Having declared on the VIII Congress of the RCP (b) in 1919 a new course for the creation and strengthening of an alliance of the working class with middle peasants, in practice until the end of the 1920s the Bolsheviks continued to rely on the poor peasants-farmhands' strata of the countryside, which made the Soviet land policy power contradictory and inconsistent. This leads to a crisis in agriculture on the peninsula, which is most aggravated in 1928-29.

In spite of the transition to a new economic policy, the Party and Soviet leadership of the Crimea constantly returned to the methods of command and administration of relatively wealthy peasants, contributed to the strengthening of the process of class differentiation in the countryside, and preferred the political interests of the state over economic ones.

Based on the implementation of the policy in the countryside on the poor peasants-farmhand the Crimean authorities provided them with all possible political and economic support. For this reason, the poor peasants-farmhands were in a better financial position than low-income peasant farms, and was not interested in expanding crops and improving yields

By expanding the possibilities of leasing land and employing hired labor in agriculture in the mid-20's, power structures in the future sharply narrowed these economic and administrative measures. But this does not lead to positive results. The desire of the Soviet regime to subordinate

\footnotetext{
${ }^{41}$ ДААРК. Ф Р-652. Оп. 1. Спр. 1534. Арк. 3.
} 
private peasant interest to the state turned out to be unnatural, it led to decrease in sown areas and yields in the agricultural sector of the Crimea.

\section{SUMMARY}

The article analyzes the specificities of the implementation of the land policy by the Bolsheviks in the Crimea during the 1920's. It was determined that the Soviet authorities in every way delayed the process of giving the peasants land, constantly changing the rules of land use and interfering in the economic activities of the Crimean peasants. It is proved that the policy of the Bolsheviks in the Crimean countryside was based on the principles of political expediency, not taking into account the economic needs of the peasantry, resulting in comprehensive support for the poor peasants-farmhands, who did not have their own crops. As a result of such actions Crimean agriculture finds itself in a crisis situation.

\section{REFERENCES}

1. Третий Всероссийский съезд Советов. Госиздат, М., 1918. C. 33-47.

2. Державний архів Автономної Республіки Крим (ДААРК). Ф. 1. Оп. 1. Спр. 53. Арк. 80.

3. Российский центр хранения и изучения документов новейшей истории (РЦХИДНИ). Ф. 17. Оп. 16. Д. 178. Л. 15-16.

4. Ішин А. В. Антибільшовицькі виступи у Криму і боротьба 3 ними (кінець 1920-1925 рр.): автореф. дис... канд. іст. наук : спец. 07.00.01 Історія України. Дніпропетровськ, 2002. 20 с.

5. Государственный архив Российской Федерации (ГА РФ). Ф. Р-1247. Оп. 1. Спр. 38. Арк. 1-12.

6. ДААРК. Ф. 1. Оп. 1. Спр. 71. Арк. 7.

7.Хронологическое собрание законов, указов Президиума Верховного Совета и постановлений правительства РСФСР. Том. 1. М., 1949. 565 c.

8. Земельный Кодекс РСФСР. М., 1923. 126 с.

9. РЦХИДНИ. Ф. 23. Оп. 14. Спр. 185. Арк. 14-15

10. ЦГА РФ. Ф. 2313. Оп. 13. Спр.148. Арк. 9

11. Сталин И. Сочинения. Госполитиздат. М., 1947. Т. 7. С. 357.

12. РЦХИДНИ. Ф. 17. Оп. 16. Спр. 118. Арк. 15.

13. ЦГА РФ. Ф. 2313. Оп. 14. Спр.117. Арк. 28-30.

14. ДААРК,. Ф. Р-30. Оп. 2. Спр. 7. Арк. 84. 
15. Народное хозяйство Крыма за 1927/1928 год. Симферополь., 1929. $32 \mathrm{c}$.

16. Красный Крым, 1924, 1 марта.

17. ЦГА РФ. Ф. 2313. Оп. 16. Спр.18. Арк. 123.

18. ДААРК. Ф. 1. Оп. 1. Спр. 920. Арк. 58, 69, 90.

19. Красный Крым, 1924, 20 февраля.

20. ДААРК. Ф Р-652. Оп. 1. Спр. 1534. Арк.

Information about the author: Horiunova Y. O. $\mathrm{PhD}$ (History), Associate Professor at the Philosophy and History Department V. Vernadsky Taurida National University Kudri Str., 33, Kyiv, Ukraine 